\title{
PENGARUH ANXIETY TERHADAP HASIL BELAJAR MATEMATIKA SISWA MASA PANDEMI DENGAN BANTUAN "GARDU”
}

\author{
Putri Nabila Masduki \\ Tarbiyah, Institut Agama Islam Negeri Kudus \\ nabiellamasduki@gmail.com
}

\begin{abstract}
This article discusses the effect of anxiety on the learning process of mathematics during a pandemic. Mathematics is a subject that is considered difficult and feared by students. This study uses two types of data, namely primary and secondary data. Primary data were obtained from observations while secondary data were obtained from literature studies. This is because mathematics is abstract, full of numbers and formulas, and requires a lot of practice. In addition, the monotonous teaching method by the teacher will increase students' feeling of boredom and not understanding the material. Students' anxiety and fear of mathematics greatly affects student learning outcomes. In the current pandemic conditions, teaching and learning activities are diverted online. In addition, from the health side of students, this condition might be a cause of anxiety in students. Teachers have an important role in the student learning process, namely to improve student learning outcomes. The current conception of a pandemic makes students even more confused about the patterns and methods of learning mathematics at home. The author tries to use the help of GARDU (Game Card For Education) to reduce the anxiety level of MTs NU AlHidayah students in mathematics lessons. By referring to primary and secondary data from both observations and literature studies, it was found that the most dominant was chosen by the respondents, namely 18 and 16 respondents respectively. The seventh statement reads "I'll recommend using GARDU to other students so that they can feel the benefits of using it".
\end{abstract}

Keyword: Anxiety, Learning Media, GARDU(Game Card For Education)

\begin{abstract}
Abstrak. Artikel ini membahas tentang pengaruh kecemasan dalam proses pembelajaran matematika di masa pandemi. Matematika merupakan salah satu pelajaran yang dianggap sulit dan ditakuti oleh siswa. Penelitian ini menggunakan dua jenis data yaitu data primer dan sekunder. Data primer diperoleh dari observasi sedangkan data sekunder dari hasil studi literatur. Hal ini karena matematika memiliki sifat yang abstrak, penuh angka dan rumus, dan memerlukan banyak latihan. Selain itu juga, metode mengajar oleh guru yang monoton akan menambah siswa merasa bosan dan tidak memahami materi. Kecemasan dan ketakutan siswa terhadap matematika sangat mempengaruhi hasil belajar siswa. Dalam kondisi pandemi saat ini, kegiatan belajar mengajar yang dialihkan secara daring. Selain itu dari sisi kesehatan peserta didik kondisi ini mungkin saja menjadi penyebab timbulnya kecemasan pada siswa. Guru memiliki peran penting dalam proses belajar siswa yaitu untuk meningkatkan hasil belajar siswa. Konsepsi pandemi pada saat ini, membuat siswa semakin bingung mengenai pola dan metode pembelajaran matematika di rumah.Penulis mencoba menggunakan bantuan GARDU (Game Card For Education) untuk mengurangi tingkat kecemasan siswa MTs NU Al-Hidayah dalam pelajaran matematika. Dengan mengacu pada data primer dan sekunder baik dari observasi dan studi literatur diperoleh hasil penelitian bahwa paling dominan dipilih oleh para responden yakni masing-masing dipilih oleh 18 dan 16 responden. Pernyataan ketujuh berbunyi "Saya akan merekomendasikan penggunaan GARDU kepada pelajar lain agar dapat merasakan manfaat penggunaannya".
\end{abstract}

Kata Kunci: Kecemasan, Media Pembelajaran, GARDU (Game Card For Education) 


\section{PENDAHULUAN}

"Quality education" atau dalam bahasa Indonesianya "kualitas pendidikan" menjadi salah satu indikator penting dalam mewujudkan pembangunan suatu bangsa. Kualitas pendidikan yang baik disuatu Negara akan membentuk sumber daya manusia yang kompeten dalam menghadapi segala bentuk ancaman dalam pembangunan bangsa (Dewi, 2018). Membahas mengenai kualitas pendidikan suatu Negara, hal ini erat kaitannya dengan media pembelajaran yang digunakan agar materi yang disajikan dapat dimengerti oleh pelajar. Hal serupa juga dinyatakan oleh Ekayanti pada tahun 2017 yang menyatakan bahwa kualitas pendidikan tidak terlepas dari penggunaan media pembelajaran yang tepat.

Menurut Survey Political And Economic Risk Consulatant (PERC) pada tahun 2016 menyatakan bahwa, kualitas pendidikan di Indonesia berada pada urutan ke-12 dari 12 negara di Asia (Suprapto, 2016). Hal ini menunjukan bahwa kualitas pendidikan di Indonesia masih sangat rendah. Rendahnya kualitas pendidikan akan berpengaruh terhadap kualitas sumber daya manusia. Rendahnya kualitas pendidikan di Indonesia dipengaruhi oleh minimnya penggunaan media pembelajaran yang sesuai dengan kebutuhan pelajar.

Selama ini proses pembelajaran di Indonesia masih menggunakan metode pembelajaran konvensional. Metode pembelajaran konvensional adalah metode pembelajaran dengan memberikan informasi kepada para pelajar dengan metode ceramah (Dewi, 2018). Metode pembelajaran konvensional membuat para pelajar lebih banyak mendengarkan dibandingkan memahami suatu materi yang diberikan. Penggunaan metode konvensional kurang efektif karena siswa hanya akan menjadi pendengar dalam proses pembelajaran (Andriningrum, 2015). Sehingga materi yang disampaikan sulit untuk dipahami oleh pelajar (Andriningrum, 2015). Hadirnya virus corona menyebabkan kerugian bagi berbagai sektor termasuk pada sektor pariwisata. Hal ini dapat kita lihat pada kasus virus corona yang terjadi di Jawa Timur. Menurut pernyataan dari ahli Epidemologi dari Universitas Indonesia, Pandu Riano, dalam harian Kompas Selasa, 9 Juni 2020 bahwa penyebaran virus yang terjadi di Jawa Timur disebabkan oleh belum teredukasinya masyarakat terhadap kesiapsiagaan khususnya pada Hari Raya Idul Fitri yang memungkinkan tingginya tingkat interaksi masyarakat. Kerugian tersebut ditunjukan dengan data penurunan jumlah kunjungan yang terjadi di Bali sebesar 50\% (Budiyanti, 2020).

Selain itu, merebaknya virus Covid-19 yang bersumber dari negara China menyebabkan pemerintah Indonesia terpaksa melakukan pembatasan penerbangan dimulai dari tanggal 5 Februari 2020 (Budiyanti, 2020). Hal ini menyebabkan penurunan jumlah wisatawan serta penghasilan pada sektor pariwisata. Isolasi mandiri dilakukan untuk mencegah dan menghindari penyebaran virus Corona meluas ke masyarakat. Namun, pandemi COVID-19 membuat hampir semua orang kalang-kabut menghadapinya. Persoalan menjadi sangat serius karena yang dihadapi 
adalah ketidakpastian baru. Pandemi Covid-19 menjadi disrupsi sehingga kita perlu mengenali, mengatasi, dan mencegahnya agar ketidakpastian ini segera berakhir (Satria, 2020). Untuk mencegah penyebaran dan penularan virus Corona menyebar luas ke dalam masyarakat, pemerintah membuat serangkain kebijakan untuk menanganinya.

Hal ini memberikan imbas pada dunia pendidikan berupa kegiatan belajar mengajar yang dialihkan secara daring. Belajar secara daring dilakukan untuk mengurangi risiko penyebaran virus corona. Pembelajaran secara daring tentunya menghadirkan polemic tentang peraturan dan kebijakan tersebut. Selain itu, dari sisi kesehatan peserta didik kondisi ini mungkin saja menjadi penyebab timbulnya kecemasan pada siswa.

Permainan kartu menjadi salah satu jenis permaianan yang diminati para pelajar. Berdasarkan data yang diperoleh dinyatakan bahwa $61 \%$ pelajar di Indonesia lebih gemar bermain kartu dibandingkan membaca buku (Mulyono, 2016). Pernyataan tersebut sesuai dengan fakta yang ada, hal ini dikarenakan kartu memiliki gambar yang menarik serta cara permainan yang diminati oleh pelajar. Sehingga pelajar lebih memilih bermain kartu dibandingkan dengan membaca buku. Selama ini permainan kartu dianggap dapat mengurangi waktu belajar. Namun, jika didalamnya mengandung tentang pelajaran, permaianan kartu dapat berpotensi sebagai media pembelajaran inovatif yang sesuai dengan kebutuhan pelajar.

\section{METODE}

1. Teknik Pengambilan Data: Penulis memperoleh data sekunder dengan mengadakan studi literatur pada jurnal, majalah, dan media elektronik untuk membandingkan data yang diperoleh dari eksperimen dengan data sekunder yang diperoleh dari studi literatur.

2. Teknik pengolahan Data: Data- data yang telah dikumpulkan oleh penulis merupakan data yang masih mentah dan perlu diolah. Langkah-langkah yang dilakukan oleh penulis dalam mengolah data yaitu:

a. Reduksi Data : Pada tahapan ini penulis melakukan kegiatan untuk memeriksa dan mengatur kembali data mentah yang telah dikumpulkan seperti karakteristik. Data tersebut tentunya dapat berisikan data yang belum valid maupun terdapat beberapa bagian yang tidak kita butuhkan ataupun bertele-tele sehingga dapat memperlambat proses penelitian jika disisipkan dalam data yang akan kita kaji, maka dari itu kegiatan pada tahapan ini mengenai pemilahan terhadap bagian data yang perlu diberi kode, bagian data yang harus dibuang ataupun pola yang harus dilakukan peringkasan. Tahapan ini bertujuan agar data mentah yang telah dikumpulkan tadi oleh penulis menjadi lebih sederhana dan sesuai dengan kebutuhan penulis sehingga mempermudahnya dalam 
kegiatan penarikan kesimpulan nantinya. Jadi pada tahapan ini penulis dapat dikatakan melakukan penyederhanaan dan pengkoreksian terhadap data-data umum yang diperoleh.

b. Penyajian Data: Setelah tahapan reduksi data, pada tahapan ini data yang telah dikumpulkan dan disederhanakan mengenai sifat-sifat umum sehingga tersusun kumpulan informasi sehingga memberikan kemungkinan bagi penulis untuk melakukan penarikan kesimpulan dan pengambilan tindakan. Penyajian data dilakukan dengan cara naratif atau tekstular yakni penulis menyajikan data menggunakan kalimat dan menjelaskan segala prosedur maupun hasil setelah melakukan pengamatan dari data-data yang dapat berupa sebuah gambar, tabel, grafik ataupun kejadian yang dilihat langsung oleh penulis. Penyajian data menggunakan cara nararif ini dapat memudahkan dalam memperjelas data kualitatif karena penyajian data menggunakan cara naratif telah disusun dengan bagian tema, data dan opini yang wajib menjadi bagian dari penyajian data tersebut.

3. Teknik analisis data: Data primer yang diperoleh dari hasil penelitian dan data sekunder yang diperoleh dari hasil studi literatur kemudian dianalisis secara deskriftif kualitatif. Data-data yang diperoleh ini kemudian dijabarkan secara deskriptif dan tetap mengacu pada permasalahan yang dirumuskan untuk dapat menarik kesimpulan.

\section{HASIL DAN PEMBAHASAN}

Pandemi Covid-19 menyebabkan kerugian multisektoral. Kondisi ini menyebabkan kerugian dalam berbagai bidang kehidupan masyarakat. Tidak hanya merenggut nyawa, tetapi juga mengacaukan tatanan kehidupan masyarakat dunia. Kerugian tersebut ditunjukan dengan data penurunan jumlah kunjungan yang terjadi di Bali sebesar 50\% (Budiyanti, 2020). Selain itu, merebaknya virus Covid-19 yang bersumber dari negara China menyebabkan pemerintah Indonesia terpaksa melakukan pembatasan penerbangan dimulai dari tanggal 5 februari 2020 (Budiyanti, 2020). Hal ini menyebabkan penurunan jumlah wisatawan serta penghasilan pada sektor pariwisata.

Tidak hanya menyebabkan kerugian dalam sektor pariwisata, pandemi ini juga menyebabkan kepanikan dikalangan masyarakat. Kepanikan ini muncul karena virus covid-19 tergolong jenis virus yang belum memiliki antobodi atau vaksin. Selain itu, pada awal kemunculanya masyarakat belum memahami secara dalam mengenai tata cara pencegahannya dan juga kesiapsiagaan menghadapi virus corona. Virus Corona atau Heavy Acute Respiratory Syndrome Coronavirus 2 (SARS-CoV-2) merupakan virus yang menyerang sistem pernafasan. Penyakit akibat infeksi virus ini disebut COVID-19. Virus Corona dapat menyebabkan gangguan ringan pada sistem pernafasan, infeksi paru- 
paru yang parah, hingga kematian. Severe Acute Respiratory Syndrome Coronavirus 2 (SARS-CoV-2), lebih dikenal dengan virus Corona, merupakan jenis virus corona baru yang ditularkan ke manusia. Virus ini sendiri dapat menyerang siapa saja, tidak peduli lakilaki atau perempuan, bayi atau orang tua, kaya atau miskin bukanlah alasan bahwa individu kebal terhadap virus mematikan ini. Pada 1012 Januari 2020 WHO sebagai organisasi kesehatan dunia. Setiati dan Aswar (2020: 84) dalam penelitiannya mengungkapkan bahwa pandemi infeksi virus corona 2019 (COVID19) tidak hanya dihadapi di Indonesia atau Asia, hal ini menjadi masalah yang dihadapi di lebih dari 200 negara di dunia. Indonesia juga terkena dampak COVID-19 yang parah dimana hingga akhir Maret 2020 angka kematian telah mencapai $8,9 \%$. Pada tanggal 16 Maret 2020 pemerintah mengambil kebijakan besar dalam rangka pemberantasan virus Corona yaitu dengan mengambil langkah PSBB (Pembatasan Sosial Skala Besar) sehingga dalam melaksanakan kegiatan belajar, bekerja dan beribadah di rumah, dianjurkan bagi Indonesia untuk memperketat himbauan tinggal di rumah, mengurangi penyebaran penyakit dengan cara karantina secara besar-besaran, meningkatkan pelayanan kesehatan, dan meningkatkan ketersediaan alat pelindung diri (APD).

Karantina / penguncian regional juga dapat secara signifikan meningkatkan penggandaan waktu epidemi. Kebutuhan akan pelayanan kesehatan akan semakin meningkat seiring dengan meningkatnya jumlah kasus.
Ini menggarisbawahi pentingnya melindungi petugas kesehatan dari risiko infeksi. Riset ilmiah di Indonesia juga penting untuk memberikan saran terkait kasus COVID-19. Banyak dampak yang terjadi selama pelaksanaan PSBB, bahkan dalam hal pendidikan PSBB yang begitu meluas di tanah air sehingga semua kegiatan belajar mengajar ditiadakan di sekolah dan hanya bisa dilakukan di rumah secara total, mulai dari PAUD hingga Perguruan Tinggi. Baik pendidikan formal, nonformal maupun informal semuanya melaksanakan kegiatan belajar di rumah.

Bagi siswa Sekolah Menengah Pertama (SMP) khususnya MTs NU AlHidayah tentunya hal ini tidak mudah untuk dihadapi, tidak sedikit pula yang mengalami kecemasan. Berbagai pemberitaan yang beredar tentang Covid-19 membuat mereka semakin was-was, belum lagi adanya penyesuaian baru pada sistem pembelajaran yang mereka terima. Mengubah gaya belajar tatap muka klasik menjadi selama melalui laptop atau ponsel. Jika kecemasan ini terus berlanjut tentu akan berdampak pada psikologi siswa, padahal matematika itu sendiri bukanlah sesuatu yang ditakuti, tetapi harus diterima secara terbuka sebagai bagian dari proses dalam pendidikan. Holmes (1991) dalam (Yudhanegara \& Lestari, 2017) menjelaskan bahwa jika faktor-faktor yang menyebabkan kecemasan pada siswa tidak segera ditangani dengan baik, tentunya akan mempengaruhi psikologi siswa baik ketika belajar matematika sendiri maupun 
berhadapan dengan mata pelajaran lain. Berdasarkan pemaparan Ridwan, terlihat jelas bahwa pemecahan masalah dari mata pelajaran harus dimulai dari yang sederhana agar di mata pelajaran yang lain terbiasa menanganinya dengan baik. Hurlock dalam (Maharani et al., 2018) mungkin hal ini dikarenakan matematika itu sendiri bersifat abstrak, matematika membutuhkan kemampuan dalam memahami konsep agar siswa tidak bosan dan bosan selain itu kecemasan tentang mata pelajaran matematika juga masih terjadi pada siswa.

Selain pembelajaran kooperatif di kelas matematika, ternyata self-efficacy juga sangat berpengaruh dalam menstabilkan kecemasan siswa terhadap matematika. Sebagai tokoh efikasi diri Bandura (1997) dalam ("Self-Efficacy and Has. Learning Mat. Meta-analysis," 2016) menjelaskan bahwa self-efficacy adalah pengetahuan tentang diri sendiri, dan yang menarik penilaian diri ini sangat mempengaruhi individu untuk menentukan sebuah aksi dalam mencapai tujuan yang diharapkan. Pada penelitian sebelumnya yang dilakukan oleh Efektivitas Pembelajaran Kooperatif Stad dalam Meningkatkan Attachment Behavior ("SelfEfficacy and Has. Learning Mat. Metaanalysis," 2016) berjudul Self-efficacy dan hasil belajar matematika: Meta-analysis. Dalam penelitiannya (Mat. Self Efficacy and Learning Results Mat. Meta-analysis, 2016) menjelaskan bahwa siswa yang memiliki efikasi tinggi umumnya lebih gigih dan efektif dalam menghadapi kesulitan dan kegagalan, termasuk yang berkaitan dengan pemecahan masalah dalam matematika. Penelitian lain yang telah dilakukan (Sunaryo, 2017) mengenai pengukuran efikasi diri siswa dalam pembelajaran matematika menunjukkan bahwa efikasi diri merupakan keyakinan yang dimiliki siswa, ditemukan dalam penelitiannya terdapat rata-rata skor keseluruhan siswa. Skala efikasi diri di MTs NU Al-Hidayah Getassrabi Gebog Kudus adalah 3,07, sehingga termasuk dalam kategori positif dan tentunya akan mempengaruhi cara mereka menjawab soal matematika. Pemilihan MTs NU Al-Hidayah Getassrabi Gebog Kudus sebagai lokasi penelitian ini dilaksanakan oleh peneliti pada tanggal 23 April 2021 dengan mematuhi protokol kesehatan ditemukan bahwa siswa di MTs NU Al-Hidayah tersebut sering menghadapi kesulitan dalam matematika. Rasa percaya diri siswa yang sangat rendah pada matematika, takut salah menjawab dan takut mendapat nilai jelek juga menjadi alasan siswa MTs NU Al-Hidayah kesulitan menjawab dengan percaya diri. Hal inilah yang menjadi alasan mengapa MTs NU Al-Hidayah menjadi tempat penelitian. Selain itu, konsepsi pandemi pada saat dan keputusan untuk mengarantina dan melaksanakan pembelajaran mulai 16 Maret 2020 membuat siswa semakin bingung mengenai pola dan metode pembelajaran matematika di rumah.

(Millan, 2003) "Ketakutan adalah komponen adaptif dari respon" stres "akut terhadap rangsangan yang berpotensi berbahaya (eksternal dan internal) yang mengancam untuk mengganggu homeostasis. Namun, bila intensitasnya tidak proporsional, kronis dan / atau tidak dapat diubah, atau tidak 
terkait dengan risiko nyata, ini mungkin merupakan gejala dari keadaan cemas yang melemahkan: misalnya, fobia sosial, serangan panik, atau gangguan kecemasan umum. "Dalam penelitiannya, Mark menjelaskan bahwa ketakutan adalah komponen adaptif dari respons stres, tetapi bila intensitasnya tidak kronis, itu mungkin merupakan gejala dari keadaan cemas yang melemahkan: misalnya, fobia sosial, serangan panik, atau gangguan kecemasan umum. Ini berubah menjadi gangguan kecemasan umum. ternyata kecemasan pada siswa juga dipengaruhi oleh konsep diri yang cenderung negatif, (Nuari, 2017) dalam penelitian terbarunya bahwa konsep diri negatif akan sangat berpengaruh pada siswa dalam menghadapi berbagai tantangan dalam matematika, siswa yang memiliki diri negatif. pembelajaran matematika akan mengalami kecemasan yang cukup besar. Berdasarkan pernyataan tersebut, membangun kepercayaan diri siswa sangat penting agar mereka siap menghadapi berbagai tantangan dalam matematika, guru mata pelajaran perlu bekerja sama dengan guru bimbingan dan konseling untuk membangun diri yang positif serta kepercayaan pada siswa.

Kata media berasal dari bahasa latin "medium" yang artinya perantara atau alat. Media pembelajaran adalah sekumpulan perantara atau alat yang digunakan dalam proses pembelajaran. Media pembelajaran adalah segala sesuatu yang dapat digunakan untuk menyampaikan isi materi pembelajaran seperti buku, majalah hingga kartu (Ekayanti, 2017). Berdasarkan data yang diperoleh, dinyatakan bahwa pemakaian media pembelajaran dalam proses belajar mengajar dapat membangkitkan keinginan dan minat yang baru, membangkitkan motivasi dan rangsangan kegiatan belajar, dan bahkan membawa pengaruh-pengaruh positif psikologis terhadap pelajar (Andriningrum, 2015).

GARDU (Card Game For Education) merupakan permaian kartu yang berisi tentang materi pembelajaran. Permainan ini terdiri dari 4 kelompok materi pembelajaran yaitu: Matematika, Biologi, Fisika dan kimia yang disajikan dalam kartu. Permaianan ini dimainkan oleh empat orang. Pemenang dalam permainan ini ditentukan oleh kecepatan dalam mengumpulkan kelompok kartu yang sesuai. Setelah permainan dilakukan maka pemain yang paling terakhir mengumpulkan kelompok kartu akan mendapat hukuman untuk menjawab materi pembelajaran yang sudah disiapkan.

Adapun cara permainan Gardu yaitu :

Permaian GARDU terdiri dari 4 orang.

1. Permainan diawali dengan menyusun kartu GARDU.

2. Membagikan kartu kepada pemain secara acak.

3. Setiap pemain mendapatkan 2 kartu dengankelompok kartu yang berbeda beda.

4. Setiap pemain berhak mengambil kartu pada tumpukan yang telah disusun secara bergantian

5. Apabila tumpukan kartu sudah habis maka pemain dapat mengambil kartu pada lawan. 
6. Pemenang ditentukan oleh kecepatan dalam mengumpulkan kelompok kartu yang sesuai.

$$
\text { Berdasakan praktik permainan }
$$

GARDU yang telah dilakukan, diperoleh informasi mengenai perbedaan GARDU dengan metode pembelajaran konvensional yang diuraikan dalam Tabel 01.

Tabel 1. Perbedaan GARDU dengan Metode pembelajaran Konvensional.

\begin{tabular}{|c|c|c|}
\hline$N O$ & GARDU & $\begin{array}{c}\text { Metode } \\
\text { pembelajaran } \\
\text { konvensional }\end{array}$ \\
\hline 1 & $\begin{array}{l}\text { Pembelajaran akan } \\
\text { lebih menarik } \\
\text { perhatian pelajar. }\end{array}$ & $\begin{array}{l}\text { Pembelajaran akan } \\
\text { membosankan } \\
\text { apabila guru hanya } \\
\text { memberikan } \\
\text { penjelasan. }\end{array}$ \\
\hline 2 & $\begin{array}{lr}\text { Pelajar } & \text { lebih } \\
\text { berperan } & \text { aktif } \\
\text { dalam } & \text { proses } \\
\text { pembelajarn. } & \end{array}$ & $\begin{array}{l}\text { Guru lebih berperan } \\
\text { aktif dalam } \\
\text { pembelajaran. }\end{array}$ \\
\hline 3 & $\begin{array}{l}\text { Pelajar lebih mudah } \\
\text { memahami materi } \\
\text { pembelajaran. }\end{array}$ & $\begin{array}{l}\text { Pelajar } r \text { sulit } \\
\text { memahami materi } \\
\text { pembelajaran. }\end{array}$ \\
\hline 4 & $\begin{array}{l}\text { Metode mengajar } \\
\text { akan lebih variatif, } \\
\text { tidak semata-mata } \\
\text { komunikasi verbal } \\
\text { melalui penuturan } \\
\text { guru. }\end{array}$ & $\begin{array}{l}\text { Komunikasi verbal } \\
\text { lebih dominan. }\end{array}$ \\
\hline
\end{tabular}

Berdasarakan penyajian data pada

Tabel 1 diperoleh informasi bahwa GARDU memiliki empat keunggulan dibandingkan dengan metode pembelajaran konvensional. Dengan menggunakan GARDU dalam proses pembelajaran maka pembelajaran akan lebih menarik perhatian pelajar, pelajar lebih berperan aktif dalam proses pembelajaran, pelajar lebih mudah memahami materi pembelajaran, serta metode mengajar akan lebih variatif karena tidak semata-mata menggunakan komunikasi verbal melalui penuturan guru.
GARDU (Game Card For Education) telah menjadi media pembelajaran yang kemudian diperkenalkan kepada para pelajar untuk mengetahui tanggapan mereka. Dalam kegiatan pengenalan inovasi ini, penulis menyebarkan kuesioner yang akan menghimpun data terhadap tanggapan pelajar mengenai GARDU yang telah dibuat. Responden tersebut merupakan pelajar dengan jumlah 20 orang yang berlokasi di Desa Getassrabi, Kecamatan Gebog, Kabupaten Kudus dengan tingkat pengembalian kuesioner sebanyak $100 \%$.

Tabel 2. Hasil rekapitulasi presepsi pelajar.

\begin{tabular}{|c|c|c|c|c|c|c|c|c|c|c|c|c|}
\hline SL & 10 & 4 & 3 & 8 & 4 & 4 & 18 & 7 & 16 & 1 & 75 & $37,5 \%$ \\
\hline $\mathrm{SR}$ & 4 & 3 & 8 & 4 & 2 & 3 & 2 & 4 & 3 & 3 & 36 & $18 \%$ \\
\hline $\mathrm{KK}$ & 2 & 5 & 4 & 2 & 8 & 2 & 0 & 5 & 1 & 4 & 33 & $16,5 \%$ \\
\hline $\mathrm{TP}$ & 3 & 4 & 2 & 1 & 3 & 9 & 0 & 2 & 0 & 3 & 27 & $13,5 \%$ \\
\hline $\begin{array}{c}\mathrm{TS} \\
\mathrm{S}\end{array}$ & 1 & 4 & 3 & 5 & 3 & 2 & 0 & 2 & 0 & 9 & 29 & $14,5 \%$ \\
\hline $\mathrm{Jml}$ & 20 & 20 & 20 & 20 & 20 & 20 & 20 & 20 & 20 & 20 & 200 & $100 \%$ \\
\hline
\end{tabular}

Keterangan:

$\begin{array}{ll}\text { PP } & \text { : Presepsi pelajar. } \\ \text { SL } & \text { : Selalu. } \\ \text { SR } & \text { : Sering. } \\ \text { KK } & \text { : Kadang-Kadang. } \\ \text { TP } & \text { : Tidak Pernah. } \\ \text { TSS } & \text { : Tidak sama sekali. }\end{array}$

Berdasarkan hasil dari Tabel 2 diperoleh informasi bahwa skor (Sering) muncul pada pernyataan ketujuh dan kesembilan. Kedua pernyataan tersebut merupakan pernyataan yang paling dominan dipilih oleh para responden yakni masing-masing dipilih oleh 18 dan 16 responden. Pernyataan ketujuh berbunyi "Saya akan merekomendasikan penggunaan GARDU kepada pelajar lain agar dapat merasakan manfaat penggunaannya". 
Hal ini menunjukan bahwa GARDU memiliki manfaat yang sesuai dengan kebutuhan pelajar. Dengan menyajikan materi pembelajaran dalam bentuk kartu permainan maka para pelajar lebih mudah untuk memahami materi pembelajaran. Materi yang disajikan lebih ringkas serta disajikan dalam bentuk permainan kartu yang menjadi kelebihan dari GARDU. Sehingga dapat meningkatkan kualitas pendidikan di Indonesia. Demikian pula dengan pernyataan kesembilan yang berbunyi "Saya tidak mengetahui bahwa permainan kartu dapat dijadikan sebagai media pembelajaran”. Hal ini telah menunjukan bahwa responden dominan tidak mengetahui bahwa permainan kartu dapat dijadikan sebagai media pembelajaran. Sehinggga, GARDU dapat dinyatakan sebagai suatu media pembelajaran inovatif untuk pendidikan di Indonesia.

\section{SIMPULAN}

Berdasarkan hasil penelitian terkait GARDU yang telah dilakukan penulis, dapat ditarik kesimpulan bahwa (1) GARDU (Card Game For Education) merupakan permaianan kartu yang berisi tentang materi pembelajaran dan dimainkan oleh empat orang. (2) Berdasarkan informasi yang diperoleh dengan pembagian kuesioner kepada 20 siswa, dapat disimpulkan bahwa GARDU sebagai media pembelajaran inovatif yang memiliki manfaat untuk pendidikan di indonesia. Seperti itulah rancangan sederhana dari media pembelajaran GARDU yang masih dalam tahap awal dan diupayakan untuk dioptimalisasikan pemanfaatannya. Penulis terus berupaya untuk gencar mempromosikan GARDU tersebut agar diketahui orang banyak. Hal ini bertujuan agar nantinya para pelajar dapat menggunakan GARDU sebagai media pembelajaran.

Dengan adanya media pembelajaran dalam bentuk kartu GARDU disarankan para pemakainya dapat menggunakan serta memanfaatkannya dengan baik. Sehingga dapat merasakan manfaat yang diberikan setelah penggunaan. Hasil penelitian ini diharapkan dapat menjadi sumber informasi dan referensi untuk pengembangan media pembelajaran. Sehingga berdampak positif bagi pendidikan di Indonesia. Kesimpulan yang dapat diambil dalam penelitian ini adalah mengelola kecemasan siswa. Pada saat terjadi pandemi sangat diperlukan, guru matematika harus bekerjasama dengan guru bimbingan dan konseling untuk membangun rasa percaya diri dan mengurangi kecemasan melalui efikasi diri pada mata pelajaran matematika. Berdasarkan hasil penelitian, materi selfefficacy dapat direkomendasikan untuk diterapkan di sekolah MTs NU Al-Hidayah untuk mengurangi kecemasan siswa terhadap matematika pada saat pandemi.

\section{DAFTAR PUSTAKA}

Andriningrum, Maulidta. 2015. Pengaruh Pembelajaran Dengan Media Kartu Kwartet Terhadap Motivasi Belajar Dan Hasil Belajar Matematika Siswa Kelas IX Smp Negeri 1 Bringin Kabupaten Semarang. Semarang: Universitas Kristen Satya Wacana.

Dewi, Ratna. 2018. Metode pembelajaran konvensional di Sekolah Menengah 
Atas. Jurnal Ilmu pendidikan, Keguruan, dan Pembelajaran. Yogyakarta. 2(2) : 44-52

Ekayani, Putu. 2017. Pentingnya Penggunaan Media Pembelajaran Untuk Meningkatkan Prestasi Belajar. Jurnal ilmu pendidikan. Bali. Universitas pendidikan Ganesha.

Kamil, Rahmat. 2015. Penggunaan Media Permaian Kartu Dalam Upaya Peningkatan Pemahaman Materi. Surakarta. Universitas sebelas maret.

Mulyono. 2016. Penggunaaan media kartu kwartet untuk meningkatkan kualitas pendidikan di Indonesia.
Cirebon. Universitas pendidikan Indonesia.

Suprapto. 2016. Peningkatan Kualitas Pendidikan Melalui Media Pembelajaran Kartu Bergambar Di Sekolah. Jurnal Ekonomi dan pendididikan UGM. 3(1) 